SH 221

$J_{8}$

1910 

WORK OF THE INTERNATIONAL FISHERIES COMMISSION OF GREAT BRITAIN AND THE UNITED STATES

\author{
By David Starr Jordan \\ International Fisheries Čmmissioner
}

\begin{abstract}
Paper presented before the Fourth International Fishery Congress held at Washington, U. S. A., September 22 to 26, 1908

BULLETIN OF THE BUREAU OF FISHERIES : : : : : : VOL. XXVIII, P. 181-186

Document No. 649 : : : : : : : : : : : : : : : : : : : : Issued January, 1910
\end{abstract}




$$
+x=258
$$

$F E B \leq 1$ I

\% en

$\therefore$ 


\title{
WORK OF THE INTERNATIONAL FISHERIES COMMISSION OF GREAT BRITAIN AND THE UNITED STATES.
}

\author{
$*$ \\ BY DAIID STARR JORDAN, \\ International Fisheries Commissioner.
}

The International Fisheries Commission represents a most interesting effort to settle at once a number of problems in international law, in constitutional law, in conflict of laws, in equity, and at the same time in biology, for no statute for the preservation and propagation of fishes can be effective unless the nature of the individual species, its food, its distribution, and its habits are primarily and persistently kept in view.

The boundary waters of the United States and Canada include two of the greatest fishing areas of the world. The Great Lakes constitute the greatest body of freslı water belonging to any single system, and are richer in fish life than any other. Puget Sound and the adjacent waters are part of the great Alaskan system, the region of all the world richest in salmon.

In these boundary waters the statutes of the Dominion of Canada, those of the different Provinces, and those of the different States of the American Union are more or less at cross-purposes with each other. Over Lake Erie, for example-the riclsest of the lakes in fisheries-four States and one Province claim jurisdiction, with the greatest variation in theory and practice of fish protection. In the treaty of April $1 \mathrm{I}, 1908$, an attempt is made to remedy this condition of affairs by the adoption by Great Britain and the United States of identical statutes relating to the fisheries, these statutes to :1old for a period of four years without change, except by the joint action of both nations. Under this treaty two commissioners have been appointed to draw up this code of fishery statutes. These are Hon. Sanuel Tovel Bastedo, of Toronto, as representative of Great Britain, and the present writer as representative of the United States. It is agreed that the code shall be submitted to both nations for adoption by the ist of January, 1909 .

This treaty involves a number of interesting principles: (1) Joint international action in the case of migratory animals moving from waters of one nation to those of another, in place of national control on the two sides of the boundary; (2) substitution of international legislation in this regard for that of the several 
Provinces, States, and counties; (3) the code of statutes must depend on the nature of the different species of animals it is designed to protect, the matter becoming, at bottom, one of natural history.

In nearly all cases the final key to the situation is found in artificial propagation-the development of the hatchery. This demands, however, men who are willing to study their business and to learn thoroughly the nature of the fishes concerned-the egg, the fry, and the adult. Artificial hatching is not a process. It is an art, and like all arts it must rest on science. How much of the money spent on hatcheries has been wholly wasted no one can tell, but the amount is considerable. And the value of any hatchery is determined, not by the nominal output of eggs and fry but by the brains put into the business. Each species of fish, like each plant in the garden, has its own nature and must be met on its own ground. It is set in its ways and will not conform to the habits of any otherspecies.

The species of fishes affected by this legislation are numerous, but they can be grouped into about six types, as represented by the herring, the whitefish, the red salmon of the Pacific, the black bass, the wall-eye, and the sturgeon.

The herring is a marine fish existing in incalculable numbers and swarming by the million in many places on both shores of the North Atlantic. The catch of herring in navigable waters is less than a drop in the bucket, and the fishery statutes must concern the protection and regulation of the fishing industry rather than the conservation of the herring itself.

The whitefish is a type of a group of fishes, part of them the helpless prey of the predatory fishes, the rest feeding freely on other forms, but all spawning in cooling waters, mostly in November. The eggs are large, free, and easily manipulated, so that they can be readily cared for by processes of artificial propagation. By caring for these eggs, perhaps twenty times as many young can be returned to the lake as would develop naturally. The best protection to such fishes is that of a size limit, forbidding the buying or selling of all that have not reached the degree of maturity involved in the second appearance on the spawning grounds. These fishes are fit for the table while the spawning process is going on. To forego catching them for a month or so before the spawning period, then to allow free fishing for adult fish on the part of those fishermen prepared to preserve the spawn is the best means of maintaining and increasing fisheries of this type. By this process the adult fishes are regarded as a ripened crop, which is removed to inake way for the crop of next year. In this regard we already see every prospect of success in the Great Lakes, as even under present conditions, with the present hatchery facilities, the number of fishes of this kind is steadily increasing.

To another category belongs the salmon of the Pacific coast, which feed in the sea, spawn in the rivers, ascending the streams for the inost part when 
4 years old, all individuals, male and female, dying soon after the first spawning. In this case the fish are valuable only when about to leave the sea, or in the lower courses of the rivers. When the spawn and milt is ripe the flesh of the fish is worthless. Here the problem is to allow fish enough to escape the nets and to ascend the rivers to cover the spawning grounds and to keep the hatcheries occupied. The most valuable of these species in international waters, the red salmon, spawns only in streams at the head of lakes. In Puget Sound the supply has been greatly depleted by overfishing. Under such circumstances nothing is gained by statutes regulating the size of fish. The only thing to be done is to establish seasonal or weekly closed periods, when a certain large number shall have opportunity to pass up to the lakes. In this case, nearly all the spawning grounds are in Canadian territory in the tributaries of Fraser River.

The black bass is the type of still another group of fishes. The male bass maintains his own hatchery. The eggs can not be stripped and hatched by artificial means. The male fish builds a nest, and the fertilized eggs are deposited in it. Then he stands guard over them, driving away all intruders, including the mother bass, until the hatching is complete. Then he eats some of his own young-let us hope the least active, as a contribution to natural selectionwhile the rest escape. No artificial improvement over his method is possible. In this case protection consists in preventing the catching of the immature fish and the absolute preservation of the spawning grounds from intrusion of net or hook.

Another class contains predatory fish like the wall-eye and perch, spawning in spring in warming waters, but susceptible of assistance through artificial hatching. In general, these are adequately protected by the law of the size limit, by which the immature fishes are kept from the markets. Sometimes, however, nets must be kept out of the line of their spring migrations.

Still another class is composed of the sturgeon. It reaches a great size, and when running to its spawning beds in the spring is an easy victim to the pot hunter. The vast majority of the sturgeons in our lakes have been killed for the eggs, which are made into caviar. The sturgeon thus far has resisted the attempts at artificial propagation, by reason of certain peculiarities of its own. When ripe the eggs and milt are thrown as soon as the fish is touched. When the eggs and milt are unripe they die without maturing if the fish is confined in a pond. With the sturgeon there is but one method of artificial increase-to prevent all killing for a series of years, corresponding to the years of unlimited slaughter.

To protect for their greatest usefulness the varying groups of fishes, in all the lakes, rivers, and seas of our northern boundary, is the task of the International Fisheries Commission. In so far as this commission is successful, it 
should extend the fisheries, increase the amount of available fish food, and bring about a more harmonious relation between the United States and Canada. Furthermore, it should improve the lot of each individual fisherman. If the work is successful it should furnish models for the statutes of the different States and Provinces which have like problems and like interests.

If this international project is carried out satisfactorily, the same remedy should be applied to the difficulties arising from the migration of fishes in interstate waters. The conditions are the same in Lake Nichigan, controlled by the variant statutes of four States, as in Lake Erie with her five States and Provinces.

The problem of the Columbia with its magnificent fisheries at the mercy of the inadequate, greedy, and variant statutes of Oregon, Washington, and Idaho, is far more difficult and more hopeless than that of the Fraser River and Puget Sound.

Twenty-eight years ago in my report on the salmon fisheries of the Columbia I called attention to the fact that these fisheries would be depleted or destroyed unless the Government of the United States could intervene between Oregon and Washington. In each State fishermen try to take all they ean get and the two legislatures can never agree on joint action of any kind adequate for the protection of the species. This has gone on from bad to worse until the Columbia fisheries are but a fraction of what they were in I 880 . At the present time, under the referendum laws of Oregon, all fishing above tidewater is forbidden in Oregon, and all gill-net fisling by night below tidewater limit is also prohibited. This practically closes all fishing on the Oregon side, while on the Washington side and in the spawning grounds of Idaho there is no limit of any kind. These statutes may be set aside by the courts - one or both of thembut meanwhile very few fishes reach the spawning grounds, and the fisheries four years hence will amount to nothing. All this comes from a struggle, carried into politics, between the associated (gill net) fishermen on the one hand and the owners of the fish wheels up the river on the other.

The fisheries in the other boundary waters, Lake Michigan, the Mississippi, the Ohio, and the Potomac, are all in similar bad way. For this there is no remedy eviclent except for the United States to take control of all migratory animals of commercial value and to control and legislate for the interstate fisheries as it does for the interstate commerce and for the interstate weather. Matters of importance which no particular State can manage should be taken in hand by the United States. Problems which seesawing legislatures find insoluble because they can not agree on joint action are easy cnough to a national commission. In this case the machinery for investigation and control (and all control must be based on scientific investigation) already exists in tle U' nited States Bureau of Fisheries. 



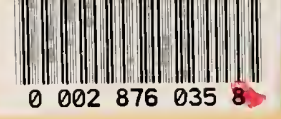




$$
\frac{J_{8}}{1910}
$$


Hollinger Corp. pH 8.5 